\title{
化学的酸化処理法による下水三次処理水中の有機物除去 一オゾン・紫外線・二酸化チタン触媒堂用いた姏理法の比較—
} 由中哲也*都築浩 一* 高木 武 夫*

\author{
Reduction of Organic Matter in Secondary Treated Municipal Wastewater \\ by Chemical Oxidation Processes \\ - Comparison of Methods Involving Ozone, Ultraviolet Radiation and $\mathrm{TiO}_{2}$ Catalyst-
}

\author{
Tetsuya TANAKA*, Koichi TSUZUKI* and Takeo TAKAGI*
}

* Mechanical Engineering Research Laboratory, Hitachi, Ltd., 502 Kandatsu, Tsuchiura, Ibaraki 300-0013 Japan

\begin{abstract}
The efficiencies of chemical oxidation of organic matter in genuine secondary treated municipal wastewater by using $\mathrm{O}_{3}, \mathrm{O}_{3} / \mathrm{UV}, \mathrm{O}_{3} / \mathrm{TiO}_{2}$, $\mathrm{UV} / \mathrm{TiO}_{2}$, and $\mathrm{O}_{3} / \mathrm{UV} / \mathrm{TiO}_{2}$ methods were compared experimentally. Effects of carbonates on these efficiencies were also investigated. Elimination of carbonates from the water increased TOC reduction efficiency for all the methods. The effect of the carbonates was less significant for the $\mathrm{O}_{3}$ method than for the other methods. The $\mathrm{O}_{3} /$ UV method was the most effective for reducing TOC under both carbonatepresent and decarbonated conditions. The least effective method was the $\mathrm{O}_{3} / \mathrm{TiO}_{2}$ under the carbonate-present condition, and the $\mathrm{UV} / \mathrm{TiO}_{2}$ method under the decarbonated condition. The catalytic ozone process $\left(\mathrm{O}_{3} / \mathrm{TiO}_{2}\right)$ showed a tendency to increase the ozonation at the beginning of the reaction under the decarbonated condition, but the addition of the $\mathrm{TiO}_{2}$ catalyst inhibited the ozonation under the carbonate-present condition. The photocatalytic oxidation process $\left(\mathrm{UV} / \mathrm{TiO}_{2}\right)$ did not reduce TOC compared with the other methods, but it could reduce TOC over a long time; namely after six hours of treatment, TOC reduction efficiency reached $60 \%$ under the decarbonated condition and 30\% under the carbonate-present condition. And the $\mathrm{O}_{3} / \mathrm{UV} /$ $\mathrm{TiO}_{2}$ method did not show a synergistic effect of ozonation and photocatalytic oxidation.
\end{abstract}

Key words: municipal wastewater, refractory organic matter, ozonation, UV irradiation, $\mathrm{TiO}_{2}$ catalyst

\section{1.はじめに}

下水道処理人口の増加に伴い生物化学的酸票要求嗇 (BOD) 在指標とした水㻴境污染は改善が見られるが，化 学的酸素要求量 (COD) 安指標とすると改善が遅れてい る。こ机は現在の下水処理は活性污泥法に代表される生 物処理が主流であるため，生物難分解性有機物の除去が 不十分であることが大きな原因の一つであると言わ礼て いる1”。た，水資源有効利用の立場加方下水処理水の再 利用を図っていくことが重要であり，下水高度処理の必 琹性が高青っている。例之ば，震業用水，環境用水（湖

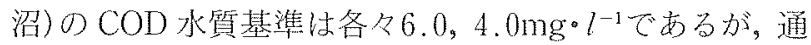
常の二次処理でこれ婳足与ることは困難である゙。

近年，下水の高度処理法としてオゾン処理の導入が広 がりつつある。しかし，オゾン好理は主として殺囷，脱 臭，脱色を是的として抢り，オゾン単独での難分解有機
物の分解除去能力は低い。そこで，有機污染物筫を化学 的に酸化分解する乎法として促進酸化法と呼ばれる高度 水処理技術の開発が近年盛んである。促進酸化法とは一 般にオゾン，紫外線，過酸化水素などを組み合せて水中 の有機污染物質至分解除去する処理法の総称であり，

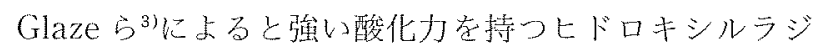
カルを效率良く生成して有機物筫它嘎化する処理法と定 義机ている。

下水高度処理索目的とした促進酸化法の研究はパイ ロットプラント規模の試験が行われている例もあ る4,5)。また，促進酸化法はこ机までに様々な手法が考案 されておりの，フェノール類など特定化学物犋の分解に ついては手法比較を行つた例は多い7,8)。しかし，実排水 走用いた下水高度処理に関する手法比較の知見は数少な い9。专た，促進酸化法では水中の炭酸イオンや典炭酸イ オンはラジカルスカベンジャーと呼ばれ，ヒドロキシル

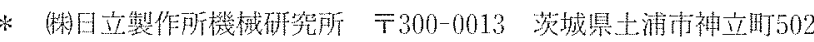


ラジカルと有機物の反応孛阻害することが知られてい る。Beltran ら ${ }^{10)}$ によと，下水一次処理水を原水として オゾン。紫外線・過酸化水素を組み合せた酸化処理を行つ た場合，炭酸・重炭酸イオンの存在がCODの除去を阻害 していることが報告されている。炭酸・重炭酸イオンの 影響についての実排水による研究例甩数少なく，下水二 次処理水を原水とした場合，あるいはその他の酸化処理

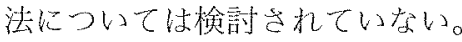

そこで本研究では幾つかの促進酸化法において夷際の 下水二次処理水（活性污泥処理水）原水とした酸化処 理実験を行い，有機物の除去特性について比較检討莸 行った。処理法としては広く知られているオゾン法 $\left(\mathrm{O}_{3}\right)$ ，オゾンと紫外線の保用洼 $\left(\mathrm{O}_{3} / \mathrm{UV}\right)$ に加えて，光 触媒法 $\left(\mathrm{UV} / \mathrm{TiO}_{2}\right)$ ，触媒オゾン法 $\left(\mathrm{O}_{3} / \mathrm{TiO}_{2}\right)$ ，オゾン と光触媒の併用法 $\left(\mathrm{O}_{3} / \mathrm{UV} / \mathrm{TiO}_{2}\right)$ 05つ0手法につい て检討した。二酸化チタンによる光触媒区応を利用した $\mathrm{UV} / \mathrm{TiO}_{2}$ 法は有機物完全分解して中間生成物ができ にくい処理法と言われており"1)，水処理への度用が期待 されている手法である。 $\mathrm{O}_{3} / \mathrm{TiO}_{2}$ 法は二酸化チタンなど の国体触媒によりオゾン処理の效率を向上させる手 法 ${ }^{2,13)}$ である。また, $\mathrm{O}_{3} / \mathrm{UV} / \mathrm{TiO}_{2}$ 法はオゾンと光触媒の 併用により相恭效果を発揮することが報告されてお り ${ }^{14)}$ ，新しい処理法として期待される。しかし，UV/ $\mathrm{TiO}_{2}, \mathrm{O}_{3} / \mathrm{TiO}_{2}, \mathrm{O}_{3} / \mathrm{UV} / \mathrm{TiO}_{2}$ 法については下水処理水 中の有機物除去特性についての知見は非常に数少ないの が現状である。さらに本研究では，酸化処理效率に影蚃 する要因の一つである炭酸種（炭酸・重炭酸イオン）の 影響について検討するため，水中の炭酸種を予め除去し た試料水学用いた实験党行った。

\section{2。実験方法}

\section{1 害験装置}

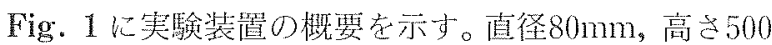
$\mathrm{mm}$ の不愬ガラ又製门筒型反応容器を用いて試料水（2

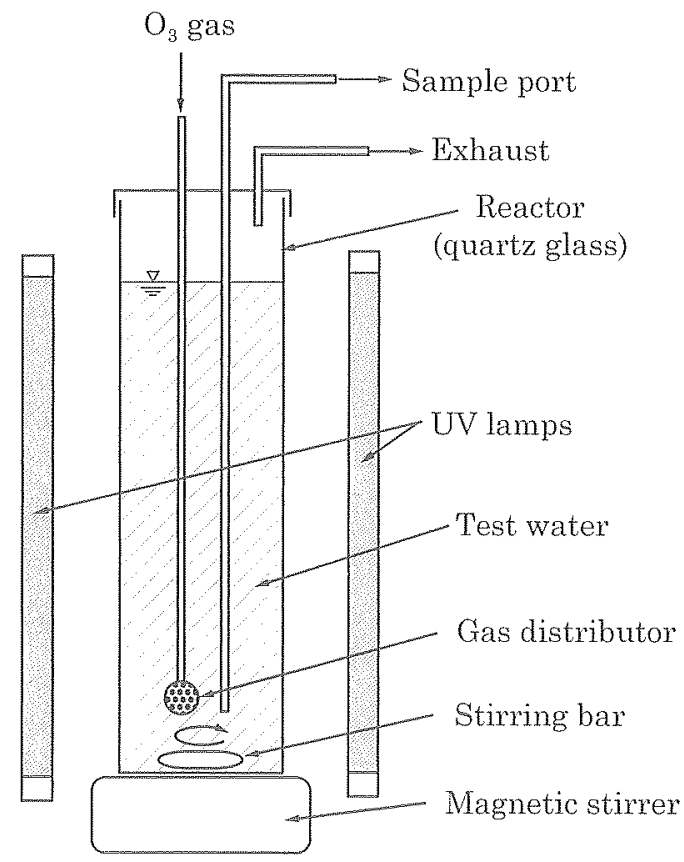

Fig. 1 Experimental reactor set-up l) 苍酸化好理し、サンプリンダポートより試料水の一部 を適時採取して分析を行った。全ての実駼に抢いて反応 中はマグネチックスターラーにより試料水を連続的に擋 挥した。

オゾン $\left(\mathrm{O}_{3}\right)$ を用いる処理法では，ガう又製の散気球 を通してオゾン化ガスを反応容器内に連続的に通気する ことでオゾン注入在行った。オゾン発生器は住交精密工 羙製，PSAオゾナイザ（SG-01-PSA2）を使用した。注 入オゾン濃度はオゾン発生器からバイパスした流路に設 堛した隔膜型ポーラログラフ電極式オゾン濃度計（東雨 電波工䍶製，OZ-20により連続的に測定した。な扔，才

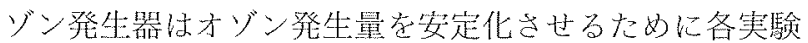
の前に十分なウォーミングアップ軍軽を㬰施した。注入 オゾン化ガスはオゾン濃度: $42 \mathrm{mg}-\mathrm{O}_{3} \cdot \mathrm{l}^{-1}$, 流量 : 160 $\mathrm{m} l \cdot \mathrm{min}^{-1}$ に設定した。よって, 試料水 1 lあたりのオゾ ン注入量は約 $3.4 \mathrm{mg}-\mathrm{O}_{3} \cdot l^{-1} \cdot \mathrm{min}^{-1}$ である。

紫外線 (UV) 劣用いる処理法では，反応容器の周国飞 設置した 4 本の $15 W$ 低圧水銀灯 (殺菌灯)により紫外線 照射老行った。この光源は主波長 $254 \mathrm{~nm}$ の紫外光老照射 寸るもので, 光源中心と反店答器中心との距離は $100 \mathrm{~mm}$ であり，光源 1 本点灯して反店容器中心付近に扔ける

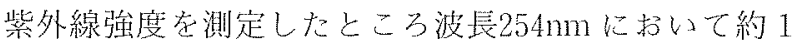
$\mathrm{mW} \cdot \mathrm{cm}^{-2}$ であった。すなお占，4本を点灯した場合は約 $4 \mathrm{~mW}^{\circ} \mathrm{cm}^{-2}$ となる。 $\mathrm{O}_{3} / \mathrm{UV}$ 法の実験に拈いて排気オゾ ン浱度老測等したところ注入オゾンの10\%以下に低下し ていたことからここの紫外線量は注入オゾンのほぼ全量 当光分解するのに十分な量であった。一方，紫外線を照 射しない埸合の排気オゾン浱度は，反応開始直後は注入 オゾンの50\%程度であったが，徐々に上昇し約 1 時間以 降は $90 \%$ 以上であった。なお，光源は点灯直後の紫外線 出力が安定しないので，ウォームアップとして各奏験の 開始前に20分以上点灯した後に実騟を行った。

触媒 $\left(\mathrm{TiO}_{2}\right)$ を用いる処理法では，触媒としてアナタ一 ゼ型の結鼠棈造を有する微粉体二酸化チタン（不原産業 製，ST-01，一次加工粒子径：7 nm) を使用した。これ を試料水中に直接添加し，均一に分散さ也るため反応開 始前に10分間擋汼した。触媒の添加濃度は文献 $6,7,15,16)$ 走 参考にして $1000 \mathrm{mg} \cdot l^{-1}$ とした。

\section{2 試料水と弚の評価法}

試料水は著者が所属す西事羓所内の排水观理瑒加ら主 としてし尿，手洗いなどの雑排水，食堂からの劂房排水 を含克生活系排水の二次処理水（活性污泥処理水）を採 取して用いた。これを $4{ }^{\circ} \mathrm{C}$ 以下で冷蔵保管し，実験每に 室温に厤してから使用した。一部の実験では炭酸。重炭 酸イオンに上る阻害の影響について調べるために，試料

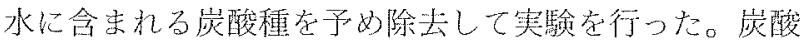
種の除去方法としては，酸性桑件下では炭酸類の溶解度 が極端に低くなることを利用して，酸性策件下で留気存 行うことにより炭酸ガスとして気相に放出させる方法を とった。具体的には試料水の $\mathrm{pH}$ を2以下に調整した後, コンプレッ少からの压縮空気により1時間の暴気を行 い, pH存もとの值に戻した。pH の調整には硫酸( $4 \mathrm{~N}$ ) 占よび水酸化ナトリウム溶液（2N）在使用した。

評俩水質項目として全有機炭素 (TOC) と $100^{\circ} \mathrm{C}$ 和け る過マンガン酸力りウムによる化学的酸素要求量 $\left(\mathrm{COD}_{\mathrm{Mn}}\right.$ ，以下筆比 CODと表記）について処理洔間（反 
応時間)に対方る経時変化を分新した。TOCの除去を図 ることができれば有機污㵽物は無機化されたことを意味 するので酸化処理性能を評俩する上で最適である。また， COD 従来から広く用いられている有機污濁指標であ るので同時に評価を行った。また，粉体触媒 $\left(\mathrm{TiO}_{2}\right)$ が 分散した試料については，遠心分漓 $(2000 \times \mathrm{g} ， 15$ 分) し た後の上澄水について分析定行った。TOCの分析は，酸 性㩧気法により無機㟶素（IC）它除去した後に全有機炭

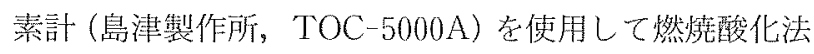
により行った。その他の水質分析は，工場排水試験法 (JIS K 0102) などに従い行った。

\section{3．实験結果および考察}

Table 1 に実験に使用した試料水(下水二次処理水) の 水質を示与。 $\mathrm{E}_{260}$ は波長 $260 \mathrm{~nm}$ に招ける紫外線吸光度

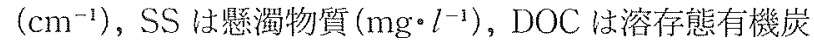
素 $\left(\mathrm{mg} \cdot \mathrm{l}^{-1}\right)$ ， BOD は生物化学的酸新要求量 $\left(\mathrm{mg} \cdot \mathrm{l}^{-1}\right)$, IC 㹥無機炭素濃度 $\left(\mathrm{mg}^{\circ} \mathrm{l}^{-1}\right)$ 表す。SS, DOC, BOD については試料水採取時に分析した值であり，その他は 実験每に分析した值の平均值である。Table 1 に示す通 り，試料水中の有機物はほとんどが溶存態成分であった。

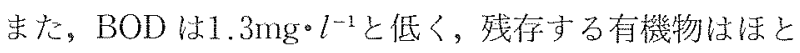
んど生物難分解性であることが䝷える。試料水中には IC として約 $200 \mathrm{mg} \cdot l^{-1}$ 炭酸種が含まれていたが，前述の 炭酸種除去操作を行った場合は ICとして $2 \mathrm{mg} \cdot \mathrm{l}^{-1}$ 程 度であった。

ここで，炭酸種の除去操作に伴う $\mathrm{pH}$ 調整㧍よび暴気 により有機物が変質することが考えられる。しかし， Table 1 に示した通り炭酸種除去操作の前後でTOC, $\mathrm{COD}, \mathrm{E}_{260}$ ともほとんど変化が見られなかったので,この ような影響は小さい电のと思われる。また， $\mathrm{E}_{260}$ の変化が 小さいことはUVを用いた実験に打いて紫外線の透過 率に差がなかったことを示している。な扮，本実験では 反応中の pH 調整は行っていない。試料水をそのまま用 いた実験では実験終了後の $\mathrm{pH}$ 変化はほとんどなかった (pH8.4 9.0,平均8.8)。炭酸種を除去した試料水の場合 は，除去操作での $\mathrm{pH}$ 調整により $\mathrm{pH}$ 緩衝能が低下する ため，実験終了後の $\mathrm{pH}$ は若干低下した $(\mathrm{pH} 6.5 \sim 7.6$, 平均 7.0$)$ 。

\section{1 炭酸㣫有無の影響}

Fig。2に各手法により試料水をそのま娄用いた場合 と炭酸種索除去した場合の処理眝間に対する TOCの変

Table 1 Characteristics of test waters

\begin{tabular}{|c|c|c|c|c|c|c|c|c|}
\hline Water samples & $\begin{array}{c}\mathrm{TOC} \\
\left(\mathrm{mg} \cdot l^{-1}\right) \\
\end{array}$ & $\begin{array}{c}\mathrm{DOC} \\
\left(\mathrm{mg} \cdot l^{-1}\right) \\
\end{array}$ & $\begin{array}{l}\mathrm{COD}_{\mathrm{Mn}} \\
\left(\mathrm{mg} \cdot \mathrm{l}^{-1}\right) \\
\end{array}$ & $\begin{array}{c}\mathrm{BOD} \\
\left(\mathrm{mg} \cdot l^{-1}\right) \\
\end{array}$ & $\begin{array}{c}E_{260} \\
\left(\mathrm{~cm}^{-1}\right) \\
\end{array}$ & $\begin{array}{c}\mathrm{SS} \\
\left(\mathrm{mg} \cdot \mathrm{l}^{-1}\right)\end{array}$ & $\begin{array}{c}\mathrm{IC} \\
\left(\mathrm{mg} \cdot \mathrm{l}^{-1}\right)\end{array}$ & $\mathrm{pH}$ \\
\hline $\begin{array}{c}\text { Raw test water } \\
(\mathrm{n}=5)\end{array}$ & $\begin{array}{c}6.5 \\
(6.4-6.6) \\
\end{array}$ & 6.3 & $\begin{array}{c}11.0 \\
(10.8-11.1) \\
\end{array}$ & 1.3 & $\begin{array}{c}0.21 \\
(0.20-0.21)\end{array}$ & 3 & $\begin{array}{c}204 \\
(201-207)\end{array}$ & $\begin{array}{c}8.5 \\
(8.4-8.7)\end{array}$ \\
\hline $\begin{array}{c}\text { Decarbonated } \\
\text { test water }(n=6)\end{array}$ & $\begin{array}{c}6.6 \\
(6.5-6.7) \\
\end{array}$ & - & $\begin{array}{c}10.5 \\
(9.8-11.1) \\
\end{array}$ & - & $\begin{array}{c}0.19 \\
(0.19-0.20) \\
\end{array}$ & - & $\begin{array}{c}1.7 \\
(1.3-2.2)\end{array}$ & $\begin{array}{c}8.4 \\
(8.0-8.6) \\
\end{array}$ \\
\hline
\end{tabular}
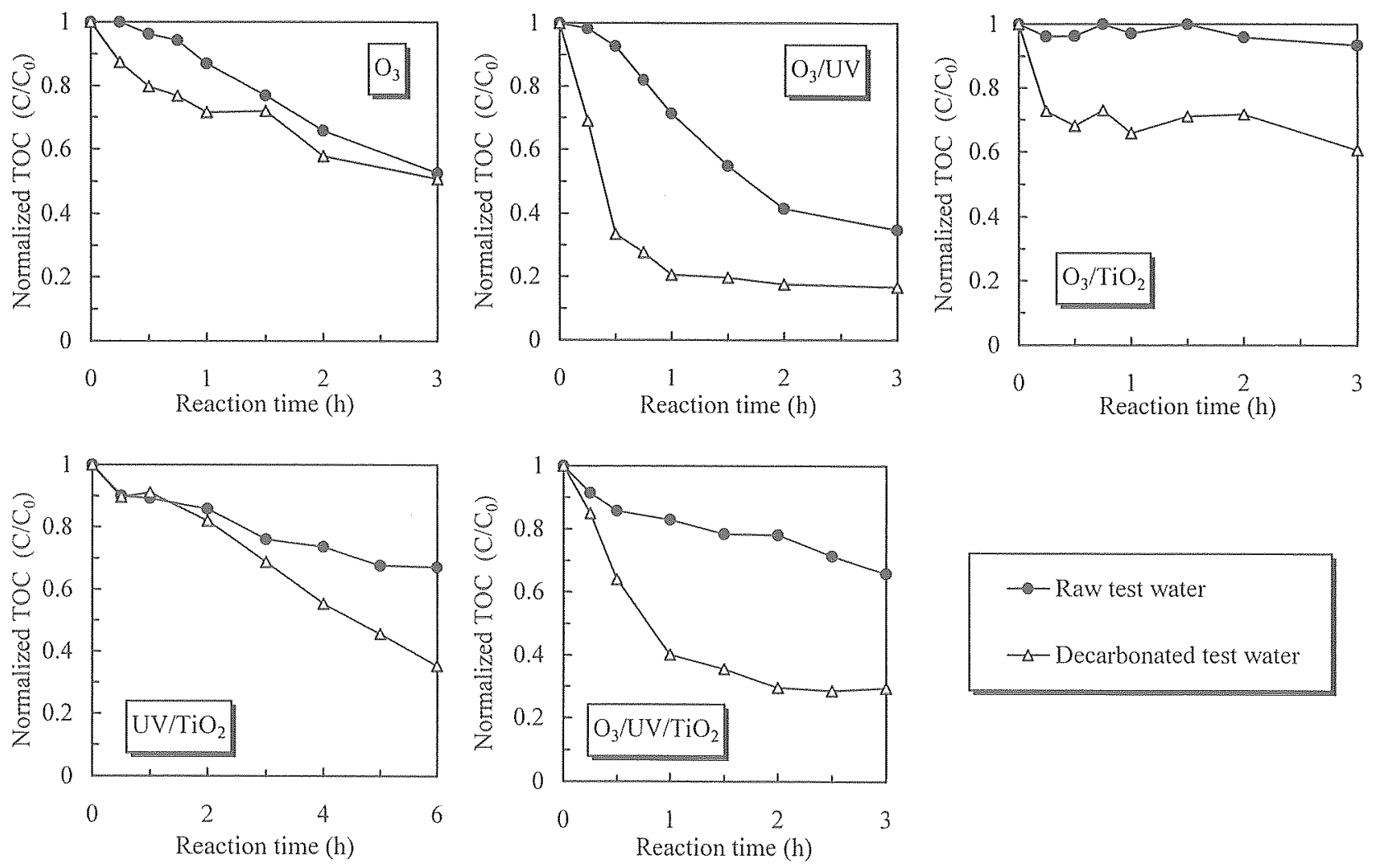

Fig. 2 Effect of carbonates on TOC reduction by $\mathrm{O}_{3}, \mathrm{O}_{3} / \mathrm{UV}, \mathrm{O}_{3} / \mathrm{TiO}_{2}, \mathrm{UV} / \mathrm{TiO}_{2}$ and $\mathrm{O}_{3} / \mathrm{UV} / \mathrm{TiO}_{2}$ methods 

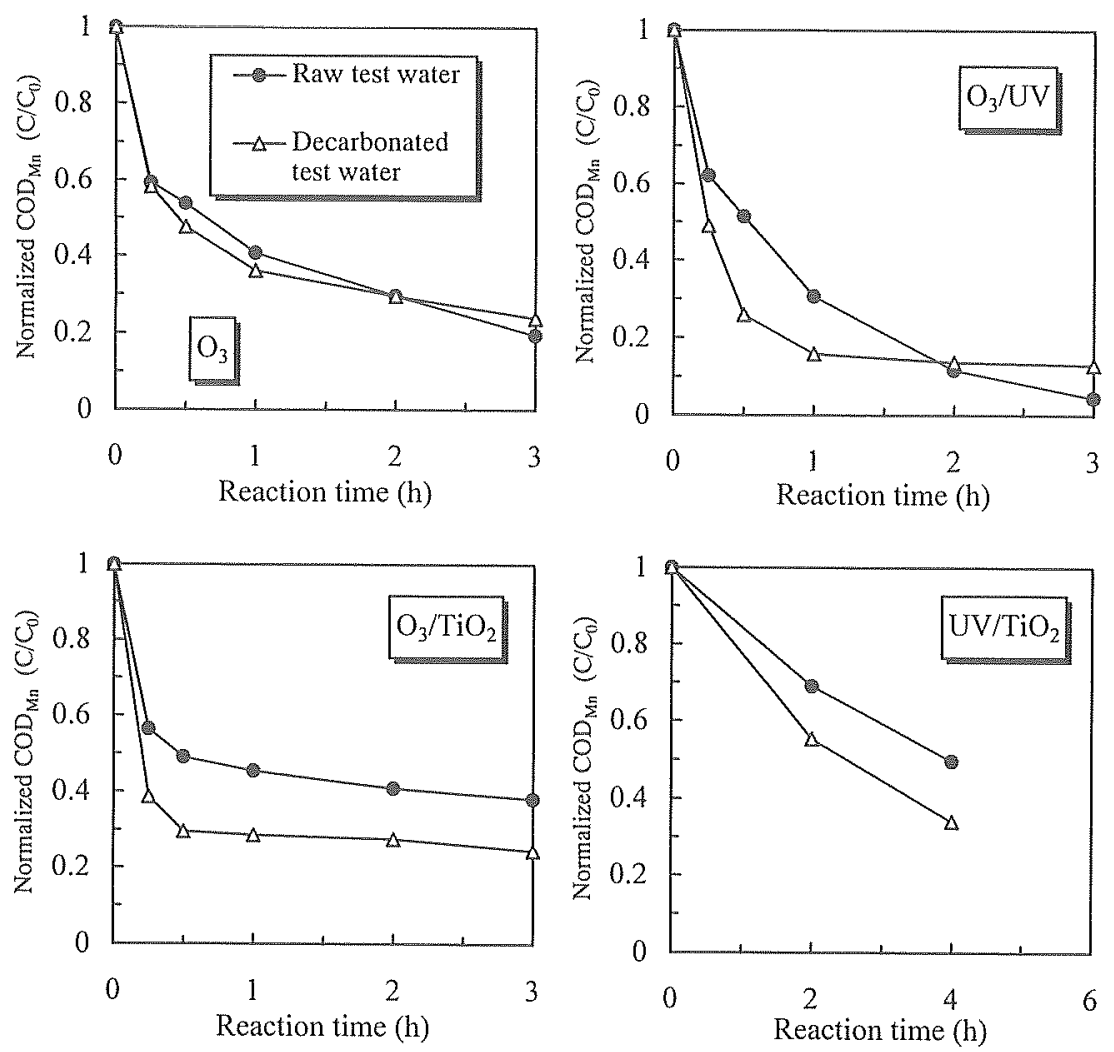

Fig. 3 Effect of carbonates on $\mathrm{COD}_{\mathrm{Mn}}$ reduction by $\mathrm{O}_{3}, \mathrm{O}_{3} / \mathrm{UV}, \mathrm{O}_{3} / \mathrm{TiO}_{2}$ and UV/ $\mathrm{TiO}_{2}$ methods

化を示し，Fig. 3 にCODの变化を示す。ここでUV/ $\mathrm{TiO}_{2}$ 法は処理時間 $0 \sim 6 \mathrm{~h}$ の結果であり, その他の手法 については 0 〜 $3 \mathrm{~h}$ の結果である。なお, TOC, COD は 初期濃度で規格化 $\left(\mathrm{C} / \mathrm{C}_{0}\right)$ して表記した。

Fig. 2 によると全ての手法に极いて炭酸種を除去す ることにより TOC 除去効率が向上しており，炭酸種に よる阻害が認められる。一方, Fig. 3 によるとCOD 除去 効率に関しても炭酸種による阻害が認められるが, TOC に比べるとその影響は小さいという傾向が窅えた。特に, $\mathrm{O}_{3}$ 法では COD 除去効率に与光る影響はほとんど見られ なかった。 $\mathrm{O}_{3}$ 法はTOC 除去についても炭酸種の影響が 小さく，反応初期にその差が見られたものの，3 h での TOC 除去率はいずれも約 $50 \%$ であった。これは $\mathrm{O}_{3}$ 法で はラジカル反応ではなくオゾンによる直接的な反応が主 体であるため, 炭酸種の存在がラジカルスカベンジャー として作用しなかったものと考光られる。

一方，オゾンと紫外線を併用する処理法 $\left(\mathrm{O}_{3} / \mathrm{UV}, \mathrm{O}_{3} /\right.$ $\left.\mathrm{UV} / \mathrm{TiO}_{2}\right)$ では, 紫外線によるオゾンの分解により生成 されるヒドロキシルラジカルの反応が主体的と考光られ るため, ラジカルスカベンジャーとしての阻害が顕著に 現れた。1 hでの TOC 除去率で見ると, 炭酸種を除去す ることにより $\mathrm{O}_{3} / \mathrm{UV}$ 法では約 $30 \%$ から $80 \%, \mathrm{O}_{3} / \mathrm{UV} /$ $\mathrm{TiO}_{2}$ 法では約 $20 \%$ から $60 \%$ に除去率が向上した。UV/ $\mathrm{TiO}_{2}$ 法について見ると， $\mathrm{TOC}$ 変化が緩やかな反応初期 （０３h）はその影響はほとんど見られなかったが，そ れ以降 ( $3 \mathrm{~h}$ 以降) は影響が現れ，6 h での TOC 除去率 は炭酸種を除去することで約 $30 \%$ から $60 \%$ に向上した。 このことから $\mathrm{UV} / \mathrm{TiO}_{2}$ 法についてもラジカル反応が主 体であったものと推察される。
$\mathrm{O}_{3} / \mathrm{TiO}_{2}$ 法については, Volk ら ${ }^{12)}$, Allemane ら ${ }^{13)}$ によ ると触媒オゾン処理はラジカル反応の寄与が小さいた め，炭酸・重炭酸イオンの影響は小さいと言われている。 しかし，Fig. 2 に示した通り本実験では TOC 除去効率 に関して炭酸種の阻害が大きく, 炭酸種が存在する場合 は TOCをほとんど除去できなかった。 $\mathrm{TiO}_{2}$ 触媒がラジ カルの生成に寄与するとは考えにくいので，ラジカルス カベンジャーとは別の作用による阻害が現れたものと思 われる。

\section{2 各手法の比䡖}

Fig. 2 抢よびFig. 3 の結果より, 炭酸種の有無に関 わらず $\mathrm{O}_{3} / \mathrm{UV}$ 法が TOC, COD ともに最も高い除去効 率を示した。TOC除去に関して見ると, 炭酸種が存在す る場合は $\mathrm{O}_{3} / \mathrm{TiO}_{2}$ 法の除去効率が最も低く, 炭酸種を除 去した場合は $\mathrm{UV} / \mathrm{TiO}_{2}$ 法の除去効率が最も低加った。 $\mathrm{COD}$ 除去に関して見ると TOC, $\mathrm{COD}$ ともに UV $/ \mathrm{TiO}_{2}$ 法の除去効率が最も低かった。

以上の結果から各手法の特徵について得られた知見を 以下に述べる。

1) $\mathrm{O}_{3}$ 法

前述のように $\mathrm{O}_{3}$ 法では炭酸種による阻害の影響が他 の手法に比べて小さく，ヒドロキシルラジカルによる酸 化反応よりもオゾンの直接反応が主体であると推察され る。また， $\mathrm{O}_{3}$ 法では TOCに比べて COD は速やかに低下 し、オゾンの直接反応によりCODの除去は容易に行え るものと思われる。

2) $\mathrm{O}_{3} / \mathrm{UV}$ 法

オゾンと紫外線の併用法は紫外線の照射によりオゾン が分解して効率良くヒドロキシルラジカルを生成するこ 


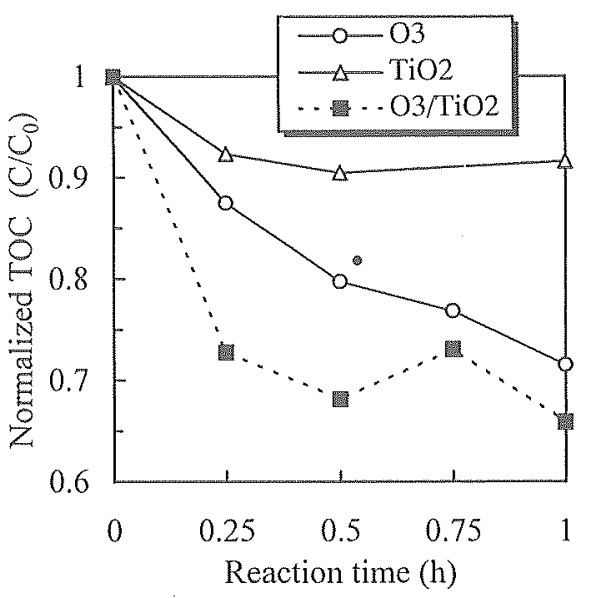

Fig. 4 TOC reduction by $\mathrm{O}_{3}, \mathrm{O}_{3} / \mathrm{TiO}_{2}$ and $\mathrm{TiO}_{2}$ (adsorption) methods (decarbonated test water)

とのできる手法として知られている。本実駼でも $\mathrm{O}_{3} / \mathrm{UV}$ 法が最も短時間でTOC，CODともに低隇できる結果と なった。しかし，前述の通りラジカル反応が支配的な酸 化処理であるため炭酸種による阻害の影響が大きく，炭 酸種の存在により TOC, COD ともに除去効率が低下し た。ここで，炭酸種が存在する場合で $\mathrm{O}_{3} / \mathrm{UV}$ 法と $\mathrm{O}_{3}$ 法 を比較すると，反心初期（処理時間 $0 \sim 0.5 \mathrm{~h}$ ）は TOC, COD 除去効率ともに雨者の差は小さい。この結果はオゾ ン注入初期は紫外線照射による併用效果が小さかったと いう高橋らの報告 ${ }^{4}$ と同じ傾向である。以上のことから， 炭酸種が存在する条件下で短時間（低オゾン注入率）で 処理を行う場合は，紫外線照射に必要なコス卜圭考点す ると $\mathrm{O}_{3} / \mathrm{UV}$ 法よりも $\mathrm{O}_{3}$ 法が有利であることが推察さ れる。

3) $\mathrm{O}_{3} / \mathrm{TiO}_{2}$ 法

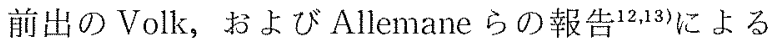
と，二酸化チタンなどの固体触媒表面に打ける有機物吸 着作用によりオゾン処理効率を向上させる手法である。 前述の通り，本実験では炭酸種が存在する条件では触媒 の添加により逆に $\mathrm{O}_{3}$ 処理を阻害する結果となった。炭酸 種を除去した条件では短時間（（－1.5h）の処理におい て $\mathrm{O}_{3}$ 処理に比べて TOC, COD 除去効率を向上させる傾 向が見られた。ただし，この結果は触某表面での吸着作 用による有機物除去を含んだ結果である。そこで暗条件 かつオゾン注入なしで触媒 $\left(\mathrm{TiO}_{2}\right)$ のみを添加した条件 の実験を行った。Fig. 4 に炭酸種を除去した場合の $\mathrm{O}_{3}$, $\mathrm{O}_{3} / \mathrm{TiO}_{2}, \mathrm{TiO}_{2}$ (吸着のみ) 法に扮ける $\mathrm{TOC}$ の变化を示 す。吸着により TOC は速やかに約 $10 \%$ 低下し，好理時間 に対してほぼ一定值で推移した。 Fig. 40結果を整理 し， $\mathrm{TiO}_{2}$ 吸着による $\mathrm{TOC}$ 除去率と $\mathrm{O}_{3}$ 処理による $\mathrm{TOC}$ 除去率を加算したものと $\mathrm{O}_{3} / \mathrm{TiO}_{2}$ 処理による TOC 除去 率を比較した結果定 Fig. 5 に示す。処理時間 $0.25,0.5$ h では $\mathrm{O}_{3} / \mathrm{TiO}_{2}$ 処理による $\mathrm{TOC}$ 除去率は $\mathrm{TiO}_{2}$ 吸着と $\mathrm{O}_{3}$ 処理を加算した除去率上りも大さく，触媒作用と思われ

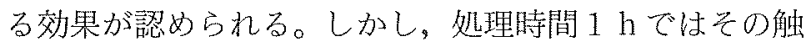
媒効果は見られなかった。以上のことから $\mathrm{O}_{3} / \mathrm{TiO}_{2}$ 法 は，炭酸種が存在しない条件で短時間(低オゾン注入率) の処理を行った場合に $\mathrm{O}_{3}$ 法よりも有効であることが示 晙された。

4) $\mathrm{UV} / \mathrm{TiO}_{2}$ 法

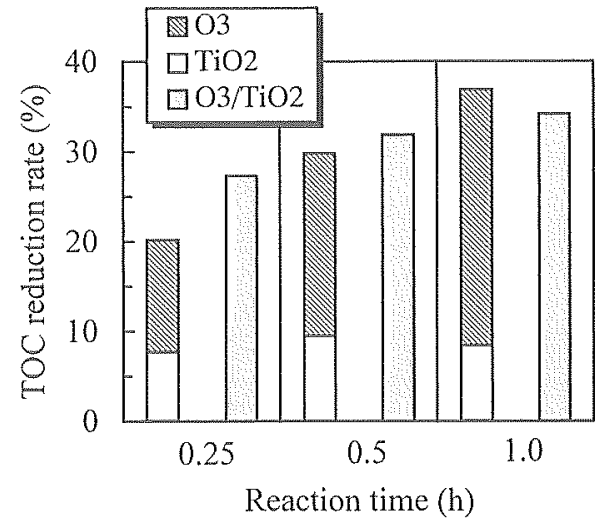

Fig. 5 TOC reduction rate by $\mathrm{O}_{3}, \mathrm{O}_{3} / \mathrm{TiO}_{2}$ and $\mathrm{TiO}_{2}$ (adsorption) methods (decarbonated test water)

$\mathrm{UV} / \mathrm{TiO}_{2}$ 法と $\mathrm{O}_{3}, \mathrm{O}_{3} / \mathrm{UV}$ 法の比較について過去の研 究例7,17)を兄ると対象物質や処理条件により異なるため 一概には言えないが，本実験では UV $/ \mathrm{TiO}_{2}$ 法は他の手 法と比較すると TOC, COD, ともに除去効率が低かっ た。特にCODに関して他手法との差が顕著であった。こ れは他の手法はオゾンを利用しているのでオゾンの直接 反応によって CODが速やかに低下したものと考无られ

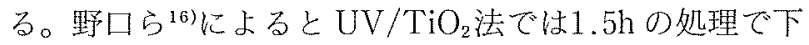
水二次処理水中の TOC をほとんど除去することができ ないと報告されおり，本実験結果と一致した。しかしな がら，本笑験では合計 $6 \mathrm{~h}$ の長時間処理を行ったとこ 万, TOC 除去率は炭酸種が存在する場合は約 $30 \%$ ，炭䧈 種を除去した場合は約 $60 \%$ が得られた。このようにUV/ $\mathrm{TiO}_{2}$ 法は反応速度は低いものの長時間の処理により下 水処理水中の有機物除去が可能であることがわかった。

5) $\mathrm{O}_{3} / \mathrm{UV} / \mathrm{TiO}_{2}$ 法

本手法は $\mathrm{O}_{3} / \mathrm{UV}$ 法と光触媒反応を併用することによ り処理効率を向上させることを狙ったが，Fig. 2 より本 実験ではオゾンと光触媒の相垂効果は見られず，むしろ $\mathrm{O}_{3} / \mathrm{UV}$ 法に比べて TOC 除去効率が低下した。これは試 料水中に分散した粉体触媒が紫外光の透過を妨害すると いう垔影響が顕著に現れた結果であると考えられる。ま

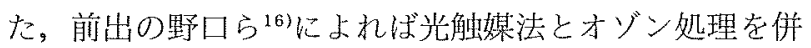
用した場合，波長 $254 \mathrm{~nm}$ の紫外線はオゾンによる吸収が 大きいため，光触媒反応の效果が現れ難いとしている。 そこでオゾンに吸収されにくい波長の紫外線を発するブ ラックライト(主波長 $352 \mathrm{~mm}$ ) 劣用いて光触媒とオゾンを 併用することで $\mathrm{O}_{3} / \mathrm{UV}$ 法と同等な好理効率が得られた と報告している。本実験では紫外線の主波長は254nmで あり，触媒添加濃度も固定としたが，今後 $\mathrm{O}_{3} / \mathrm{UV} / \mathrm{TiO}_{2}$ 法を検討する場合は光源の波長域や触媒添加濃度などに ついてさらに検討する必要がある。

\section{4.まとぬ}

下水好理水中の有機物除去を目的としてオゾン $\left(\mathrm{O}_{3}\right)$ ， 紫外線 (UV)，二酸化チタン触媒 $\left(\mathrm{TiO}_{2}\right)$ を組み合せた 化学的酸化処理法 $\left(\mathrm{O}_{3}, \mathrm{O}_{3} / \mathrm{UV}, \mathrm{O}_{3} / \mathrm{TiO}_{2}, \mathrm{UV} / \mathrm{TiO}_{2}\right.$, $\mathrm{O}_{3} / \mathrm{UV} / \mathrm{TiO}_{2}$ ) について実際の排水を用いて实験的に比 較検討した。同時に炭酸種の有無が有機物除去に与える 影響について検討した。結果より以下の知見が得られた。

1) 全ての処理法に扔いて炭酸類を予め除去すること 
でTOC 除去効率が向上し，炭酸㣫の存在による阻害が 見られた。COD除去に対しても炭酸種による阻害が見ら れたが，TOC 除去に比べるとその影響は小さかった。

2) $\mathrm{O}_{3}$ 法は他の手法に比べて炭酸種による影響が少 なかった。特にCOD除去に対してはほとんど影響がな かった。

3) TOC 除去效率は炭酸種の有鲢に関わらず $\mathrm{O}_{3} / \mathrm{UV}$ 法が最も高く，炭酸種が存在する場合は $\mathrm{O}_{3} / \mathrm{TiO}_{2}$ 法，炭 酸種を除去した場合は UV $/ \mathrm{TiO}_{2}$ 法が最も低かった。 COD 除去効率は崖酸種の有無に関わらず $\mathrm{O}_{3} /$ UV 法が 最も高く，UV $/ \mathrm{TiO}_{2}$ 法が最も低かった。

4) $\mathrm{O}_{3} / \mathrm{TiO}_{2}$ 法は $\mathrm{O}_{3}$ 法に比べて炭酸種を除去した場 合は反応初期に TOC 除去効率が向上したが，それ以降 は明確な效果は見られなかった。炭酸種が存在する場合 はかえって除去效率を低下させた。

5) $\mathrm{UV} / \mathrm{TiO}_{2}$ 法は他手法に比べて TOC除去効率が 低かったが，長時間の処理によりTOC除去が可能で 古った。

6) $\mathrm{O}_{3} / \mathrm{UV} / \mathrm{TiO}_{2}$ 法は $\mathrm{O}_{3} / \mathrm{UV}$ 法と比べて炭酸種の有 無に関わらずTOC 除去効率が低下し，本実験では光触 媒とオゾンの相乘効果は見られなかった。

なお，本研究は科学技術庁の平成10年度科学技術振㦛 調整費による「相模湖・津久井湖の藻類による污濁機構 解明とその净化・資源化技術に関する研究」の一謤とし て行われたものである。

\section{(原稿受付 1999年6月11日)} (原稿受理 1999年8月2日)

\section{参考 文 献}

1) 和田英太郎, 安成哲三 編 (1999) 岩波講座地球㻴境学 4 「水・ 物質循環系の変化」，269pp，岩波書店，東京.

2）高橋正策，弓倉純一，若山正害（1998）水環境及び再利用用途 に広じた水処理技術に関卞る調查，日本下水道事業団技術開発部 技街開発部報, pp.93-101.

3) Glaze, W.H., Kang, J.W. and Chapin, D.H. (1987) The Chemistry of water treatment involving ozone, hydrogen peroxide and ultraviolet radiation, Ozone Science \& Engineering, 9, 335-352.

4）高橋正策，野月宏美，若林渟司（1996）オゾン・紫外線・活性 炭を使った二次処理水の処理, 第34回下水道研究発表会講演集, pp.587-589.

5) 河相好莩, 安永望, 廣过淳二 (1997) 過酸化水素添加オゾン処 理法に上る水再生技術，第 6 回日本オゾン協会研究講演会講演 集, pp.24-27.

6) Huang, C.P., Dong, C. and Tang, Z. (1993) Advanced chemical oxidation : its present role and potential future in hazard ous waste treatment, Waste Management, 13, 361-377.

7) Ruppert, G. and Bauer, R. (1994) UV- $\mathrm{O}_{3}, \mathrm{UV}-\mathrm{H}_{2} \mathrm{O}_{2}$, UV $-\mathrm{TiO}_{2}$ and the photo-Fenton reaction-comparison of advanced oxidation processes for wastewater treatment, Chemosphere, 28, 1447-1454.

8) Trapido, M., Veressinina, Y. and Munter, R. (1998) Advanced oxidation processes for degradation of 2,4-dichloand 2,4-dimethylphenol, Journal of Environmental Engineering, 124, 690-694.

9) Ito, K., Jian, W., Nishijima, W., Baes, A.U., Shoto, E. and Okada, M. (1998) Comparison of ozonation and AOPs combined with biodegradation for removal of THM precursors in treated sewage effluents, Water Science \& Technology, 38(7), 179-186.

10) Beltran, F.J., Garcia-Araya, J.F. and Alvarez, P. (1997) Impact of chemical oxidation on biological treatment of a primary municipal wastewater. 1 . Effects on COD and biodegradability, Ozone Science \& Engineering, 19, 495-512.

11）田中啓一（1996）光触媒を利用した排水・地下水の浄化処理, 環境管理, 32, 923-928.

12) Volk, C., Roche, P., Joret, J-C. and Paillard, H. (1997) Comparison of the effect of ozone, ozone-hydrogen peroxide system and catalytic ozone on the biodegradable organic matter of a fulvic acid solution, Water Research, 31, 650-656.

13) Allemane, H., Delouane, B., Paillard, H. and Legube, B. (1993) Comparative efficiency of three systems $\left(\mathrm{O}_{3}, \mathrm{O}_{3} / \mathrm{H}_{2} \mathrm{O}_{2}\right.$ and $\mathrm{O}_{3} / \mathrm{TiO}_{2}$ ) for the oxidation of natural organic matter in water, Ozone Science \& Engineering, 15, 419-432.

14）田中啓一（1996）光触媒とオゾンによる促進酸化処理，PPM, No.12, 10-15.

15）小浦克之，宗宮功，小野芳朗（1995）オゾン，紫外線，二酸化 チタン併用によるフミン酸の処理に関方る研究, 第32回下水道研 究発表講演集, pp.619-621.

16）野口寛，加賀美理惠，佐藤茂雄(1997)オゾンと二酸化チタン, プラックライトの併用による下水の高度処理, 第 6 回日本オゾン 協会年次研究講演会請演集, pp.28-31.

17) Mansilla, D.H., Yeber, M.C., Freer, J., Rodriguez, J. and Baeza, J. (1997) Homogeneous and heterogeneous advanced oxidation of a bleaching effluent from the pulp and paper industry, Water Science \& Technology, 35(4), 273-278. 